\title{
Economic Value as Legal Considerations for The Utilization of State-Owned
}

\author{
Pangi Suryadi ${ }^{1}$, Faisal Santiago ${ }^{2}$ \\ \{paneli.dk@gmail.com\} \\ Universitas Borobudur, Indonesia
}

\begin{abstract}
The purpose of the study was to determine the role of state property management on development and to find out the ideal legal construction of state property management so that it can reflect good governance, as well as to observe and analyze aspects of economic value as a legal basis in considering plans for the use of state property. This study also aims to determine the form of supervision on the implementation of the use of state property, as well as the responsibility if the use of state property can harm state finances. This research is directed at the normative nature of legal science so that this type of research is doctrinal or normative, namely a type of research obtained from literature studies by analyzing a legal problem through the approach of legislation, literature, and other reference materials related to utilization of state property, using a philosophical, legal, case, and conceptual approach. The types and legal materials used are primary, secondary, and tertiary legal materials, with qualitative data analysis. The results show that the role of state property is to generate profits through several contributions in accordance with the asset utilization method, maximizing the benefits of regional property resources so that the objectives of regional governance are achieved. The results showed that- (1) the nature of providing opportunities for users of goods for the planned utilization of state property has not been able to make effective use of state property, streamline state expenditures, and optimize state revenues. (2) control of the utilization of state property has not been implemented properly, because the supervision model carried out is only internal control, while external supervision has not been implemented because there are no regulations that regulate it. (3) accountability for indications of irregularities in the use of state property can be carried out in two forms, namely accountability according to administrative law, civil law. However, these two forms of accountability have not perform well.
\end{abstract}

Keywords: State Property; Utilization; lease

\section{Introduction}

Utilization of State-Owned Goods (BMN) can be carried out for BMNs that are in the use of goods, as well as those who manage goods. "There are provisions, ensuring the process of utilizing BMN can run in an orderly, directed, fair, accountable manner, to realize efficient, effective, and optimal BMN management,". Utilization of BMN can provide maximum 
contribution to the nation and state, through the entry of money into the state. BMN is all goods purchased or obtained at the expense of the State Budget or derived from other legitimate acquisitions.

The state has the right to control a concept based on the understanding that a state is an organization of power from all the people so that as the owner of power,[1] the state has the right to influence other parties. Likewise, in its power as the governing body, the state is given the task of carrying out the obligation to create prosperity for the people. Therefore, the state has power that can be "forced" to be given in terms of the use of State Property.

Theoretically, especially economic analysis based on law,[2] there are several theoretical streams that can be used as a reference for discussing state assets. Meanwhile, in the study of legal philosophy culture,[3] the discussion can be identified as an idea between postpragmatism and neo-conservatism. Postpragmatism[4] views state assets as all assets owned by the state and must be accounted for by the state, in this case the government to its people through parliament, which is reflected in the use of its state revenue and expenditure budget. However, neoconservatism[3] defines state assets as the concept of state ownership and control in any legal field, whether in public or private settings.

The view of neo-conservatism, state assets are everywhere implies the hypothesis of state sovereignty[3] which states the state as the representation of the highest power. There are three indicators of the thesis of neoconservatism in understanding state assets, namely the state as the highest power factor in the field of public law and private law, interference by state organs in the mechanism of asset inspection, and the strengthening of the influence of the state bureaucracy in the examination of the private sector.[3] If these three indicators are maintained continuously, what will happen is state tyranny in the legal field of state wealth management.[5]

The state as an organization of power, forms a government that is given the obligation to provide services to the community as stated in the 1945 Constitution of the Republic of Indonesia which is described in more detail in Law Number 25 of 2009 concerning Public Services (Public Service Law).

Public services or services to the community are carried out by empowering all existing government resources, both in the form of public goods and public services as stated in[6] Article 5 paragraph (1) of the Public Service Law. These services cover all aspects of national and state life, starting from defense, security, education, economy, health, as well as the utilization of State Property, which are carried out by government agencies in accordance with their respective fields based on good governance principles.[6]

Utilization of Property as part of the management of State Property which is carried out and managed by the state leads to one goal, namely to create the greatest prosperity of the people. That goal is the responsibility of the state as a consequence of the state's right to control the earth, water and natural resources contained therein as mandated by Article 33 of the 1945 Constitution of the Republic of Indonesia, so that to realize this, some support is needed which can be seen from the two aspects, namely the human resource aspect and the management aspect of the use of State Property.

Human resources are a determining factor in a country, if a country with human resources who have adequate skills and knowledge and master high technology, the great hope of the country will progress and develop rapidly, for example the country of Japan which was destroyed due to the bombing by the allied troops coupled with the lack of natural resources that resulted in the country being helpless, but the reality of Japan was able to rise again to become a super power country that was highly reckoned with by other countries in the world, even trade and technology had been able to outperform other countries. United States, this is because Japan has persistent and reliable human resources. If this condition is owned by the Indonesian people, 
surely the poverty level will be overcome given that Indonesia's natural wealth is extraordinary compared to other countries in the world. However, the current development of Indonesia's state assets has not been managed properly, this can be seen by the absence of an inventory effort, the inefficiency of the use of State Property.

The legal basis is not yet comprehensive and integrated, scattered locations and unclear tenure rights, weak coordination, weak supervision, conflicts of interest, and easy looting of State Property. This condition is further exacerbated by human resources who do not have the expertise so that they must bring in experts from outside which results in the exploitation of Indonesia's state assets being unavoidable, the control by foreign countries of Indonesia's natural wealth adds to the long list of poor state wealth management systems. These problems are largely the result of past mismanagement of state assets where the management of State Property is closed in the sense that there is uncertainty about who is the manager of State Property and the non-transparent process of managing state assets from planning to disposal.[7]

In addition to human resources, another factor that is no less important in realizing the responsibility of the state in creating prosperity for the people is the management of the use of State Property.[7] In general, asset management both in companies and in the state includes planning, acquisition, utilization, [8] and disposal activities. So, to do this, goverment must at least adhere to three main pillars, namely;

a. Decisions regarding asset management must be based on an evaluation of the available alternatives by considering the total costs, benefits, and risks of the asset. Example; When a government work unit requires an official vehicle as a tool to serve the community, the work unit must consider all alternatives for procuring official vehicles. So far, most of the procurement needs for official vehicles in government work units is through "buying" without considering the alternative of "renting". The work unit should carefully consider whether it is cheaper to buy or rent. If after considering the costs and benefits, it turns out that it is cheaper to rent, then why should the work unit purchase official vehicles.

b. Ownership, control/supervision, accountability, and reporting of an asset must be clearly organized, communicated to users (stakeholders), and implemented properly. If this pillar is strong, then there will be no more cases of releasing State Property to parties who are not entitled to it, as well as cases of losses experienced by the state due to reporting of unfair values in the government's balance sheet.

c. Asset management activities should fall under an integrated[9] asset management policy framework. It seems that the use of State Property has not been fully in accordance with the three pillars, so that the role and function of the government is very much needed, so that the three pillars can be carried out properly.

d. The government's steps in supporting the implementation of the use of State Property based on the three pillars are the issuance of Law Number 1 of 2004 concerning the State Treasury, specifically in chapter VII which regulates the Management of State Property, and as an implementing regulation of Law No. 1 of 2004. specifically in chapter VII, Government Regulation Number 6 of 2006 concerning Management of State Property has been issued as amended by Government Regulation Number 38 of 2008 concerning Amendments to Government Regulation No. 6 of 2006, but in its implementation,

Management of State Property is increasingly developing and complex so that it cannot be implemented optimally due to several problems that arise and management practices whose handling cannot be carried out with the said Government Regulation, so regarding this matter, PP. No. 38 of 2008 concerning Changes On PP. No. 6 of 2006 it was replaced with Government Regulation No. 27 of 2014 concerning Management of Property. 
State/Region with consideration in order to be able to answer problems and practices that have not been accommodated in previous Government Regulations, such as the dynamics of the management of state property related to leases, cooperation in utilization[10] and State Property located abroad which must be treated specifically. In addition, there are multiple interpretations of the provisions in PP. No. 6 of 2006 regarding the Public Service Agency (BLU), Non-Tax State Revenue (PNBP), as well as cases that arise in the management of state property such as the findings of the BPK examination which requires the government to perfecting PP.N0.6 Year 2006.[11]

The substance of the three regulations mentioned above, both before the amendment and after the replacement is made, are basically the same in terms of the regulation regarding the use of State Property as part of the Management of State Property, specifically regarding Article 3 paragraph (2) PP. 27 of 2014 which stipulates that "Management of State Property includes Planning for Needs and budgeting, procurement, utilization, transfer, security and maintenance, assessment, destruction, elimination, administration, and guidance, supervision and control".

The implementation of the utilization of state property is the authority and responsibility of the Minister of Finance as the Property Manager, and is functionally carried out by the Directorate General (Dirjen) of State Assets (DJKN) as one of the work units of the Ministry of Finance which specifically handles State Asset Management and is led by a Director General. (DIRECTOR GENERAL). Then the Director General may appoint officials within the Directorate General of State Assets (DJKN) to carry out some of the authorities and responsibilities of the Minister of Finance as the Property Manager. Furthermore, the Minister/head of the institution is the Property User for the State Ministry/Institution he leads, and the Head of the office within the ministry/institution is the Proxy of the Goods User within the office concerned.

The delegation of authority of the Minister of Finance as the Property Manager to the Director General as the Proxy of the Goods User is in fact often managed to obtain non-optimal returns (low returns),[12] because the granting of such authority is not followed by strict supervision,

Often policies related to the utilization of State Property are entirely the initiative of the goods user and the power of the goods user,[13] for example the case regarding the use of State Property through the State Audit Board found three problems in the management of Bung Karno's assets. Findings related to GBK revenue and administration are contained in the 2019[14] financial audit report, there are two findings related to income. First, the implementation of utilization agreements in GBK has not been optimal, such as billboards. There are still many billboards that have not been removed even though the rental period has ended and there are receipts that should be obtained but are not accepted. Second, findings related to payment of contributions that are not in accordance with the provisions. For example, there is a contract that stipulates a penalty for late payment of an agreement with a private party. However, so far no sanctions have been imposed. The results of the utilization of BMN assets, the state gets around Rp. 298 billion in 2019.[15] Indications of violation of the use of State Property through cooperation or lease often also occur in terms of setting the Rent Rate Formula, as regulated in Article 20 paragraph (1) of the PMK. No. 57/PMK.06/2016 that; "The principal rental rate in the form of land and/or buildings is the fair value of the lease.[15]" This means that the rental rate formula is determined based on the fair value of the rental of state-owned goods by taking into account the adjustment factors based on the market price and condition of state-owned goods, as well as the situation, condition, and area where the state-owned goods are located. However, in practice, the determination of the rental rate formula is based on the rental capitalization rate with a definite and uniform amount for each situation, condition and 
area, so that in the field the results obtained with this formula are often not "fit" with market data (generally lower than the market data). with the prevailing tariffs in the market), so the potential for state losses is very likely to occur. As an example of the alleged corruption case in the construction of two BCA Tower towers and Kempinski Apartments, PT Grand Indonesia is alleged to have violated the BOT contract, causing state losses of Rp 1.2 trillion.[16]

Based on the explanation above, it can be seen that the utilization of State Property in the form of BOT is not yet fully orderly, transparent, and accountable. If this is allowed, it will not only result in losses for state finances, but the state will also fail to realize welfare for the community because the state is suspected of not being optimal in carrying out its obligations in utilizing State Property as mandated by law. Therefore, a further and in-depth research and study is needed in order to find the ideal steps in the utilization of State Property.

Based on the background of the problems mentioned above, there are several problems that require more in-depth study and research, namely:

1. What is the nature of providing opportunities for users of goods in the form of land and buildings for the planned utilization of State/regional Property?

2. Has the arrangement of the system for determining the rights and obligations of users of state/regional property taken into account the utilization with the concept of economic value on the implementation of the utilization of state property in the form of a cooperation scheme of lease agreement or build-to-delivery (BOT)?

\section{Methods}

The research methodology used is normative juridical research. Because the main object is a norm or rule, but also examines its empirical aspects. While the nature of the research used is descriptive research, namely to describe the use of state property with a cooperation scheme of lease agreement or build-to-delivery (BOT) by considering the basis of the study of the most possible and permitted use of a land or land that has been built, which is physically possible, supported or justified by regulations, financially feasible and yielding the highest and best use.

This research is a scientific way to obtain data with the aim of using it. Based on this understanding, there are four things that need to be understood, namely the scientific method, data, purpose and use. The scientific way of research means that research is based on scientific characteristics, namely rational, sociological and systematic. Rational means that research activities are carried out in ways that make sense. Then sociological means that research activities are observed by the human senses, while systematic means that the process used in research uses logical steps.[17]

\section{Analysis and Discussion}

\subsection{The Nature of Providing Opportunities for Users of Goods in The Form of Land And Buildings for The Planned Utilization of State/Regional Property}

The concept of the welfare state was initiated by Jeremy Bentham (1748-1832) with the government's responsibility to guarantee the greatest happiness (or welfare) of the greatest number of their citizens. The state is based on a welfare system by giving the state (government) a greater active role in allocating a portion of public funds in managing and organizing the economy to ensure the availability of universal and comprehensive social services to its 
citizens, [18] which is supported through 4 (four) main pillars, namely: 1) social citizenship; (2) full democracy; (3) modern industrial relations systems; and (4) rights to education and the expansion of modern mass educations systems.[19]

Based on Article 1 number 10 of Government Regulation Number 27 of 2014, what is meant by the use of state property (BMN) is the utilization of BMN/BMD which is not used for the implementation of the duties and functions of ministries/institutions/regional work units and/or optimization of BMN/BMD without changing ownership status. From this definition, it can be emphasized that there are efforts from the government to utilize BMN that is not used for the implementation of tasks and functions (idle) and to optimize BMN, so that it can provide the greatest benefit to the state. Furthermore, Article 27 states the forms of utilization of State Property, namely in the form of: (1) Rent; (2) Borrow and Use; (3) Utilization Cooperation; (4) Build for Handover (BOT) or Build Handover; and (5) Cooperation in Infrastructure Provision.[11]

PP 27/2014. The BMN management official is the Minister of Finance as BUN, the BMD management official is the Governor/Regent/Mayor. Further provisions regarding the duties and authorities of the Property Manager are regulated in Article 5 and Article 6, PP 115 of 2020.

Goods Users, in this case the Ministry/Head of Institutions, have the role of submitting proposals for the use of BMN which are under their control to the Property Manager. The BMN that is proposed to be utilized[20] by the Property User is usually in the form of land and/or buildings. The value of BMN in the form of land and/or buildings its value increases every year.

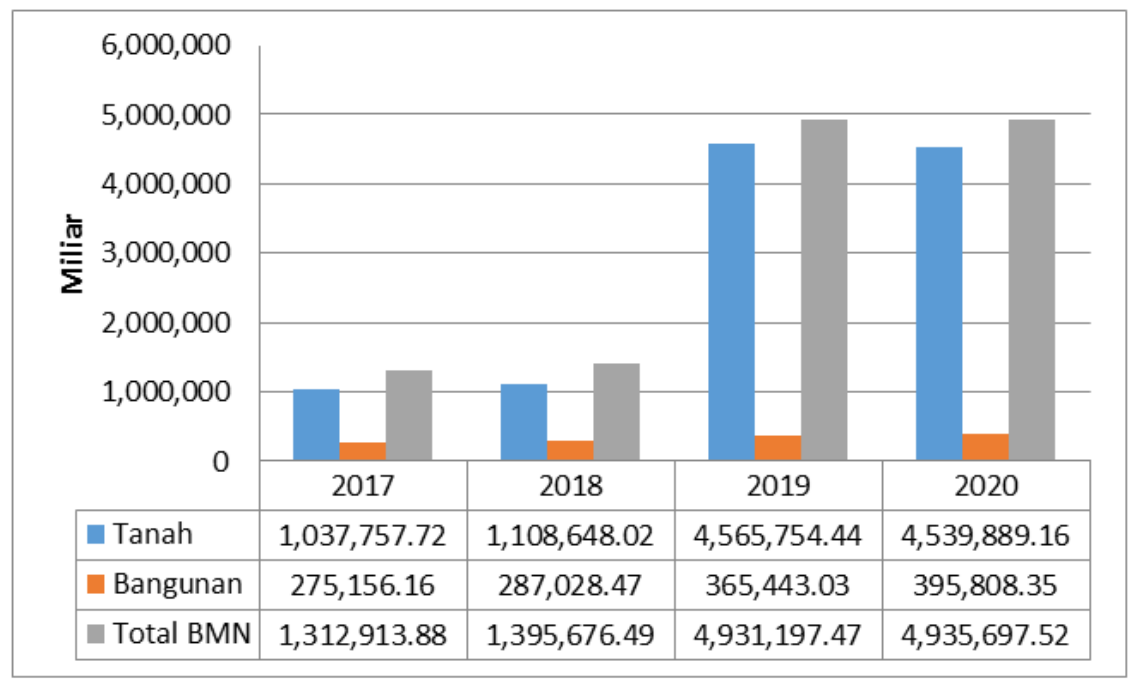

Fig. 1. Value of Land, Buildings and Buildings in 2017 - 2020 (In Billion Rupiahs) Source: Central Government Financial Report 2020 (Audited)

There was a significant increase in the value of BMN in the form of land and buildings in 2019 of Rp3,625.52 trillion. This increase comes from the reassessment of BMN carried out by the Directorate General of State Assets (DJKN) together with Ministries/Agencies from 2017 2018 and improvements are made in 2019-2020. The results of the reassessment of BMN can optimize the utilization of BMN. This BMN is in the possession of the Property User who has the authority to apply for the use of the BMN which is under his control. This is one of the 
efforts to increase the optimization of the utilization of State-Owned Goods which lies in a good understanding of the Goods Users on the potential of BMN. One of the analytical tools that can be used by Goods Users Receipts from the use of BMN have increased of Rp1,070 billion from year previously amounted to Rp505 billion to Rp1,575 billion. However, in 2020 state revenues from the use of BMN decreased compared to 2018 and 2019. However, when compared to the total value of $\mathrm{BMN}$ in the form of land and buildings owned, the percentage of revenue from BMN utilization was still quite small. The following table shows the percentage of revenue from BMN utilization based on the total BMN value of land and buildings in 2017-2020:

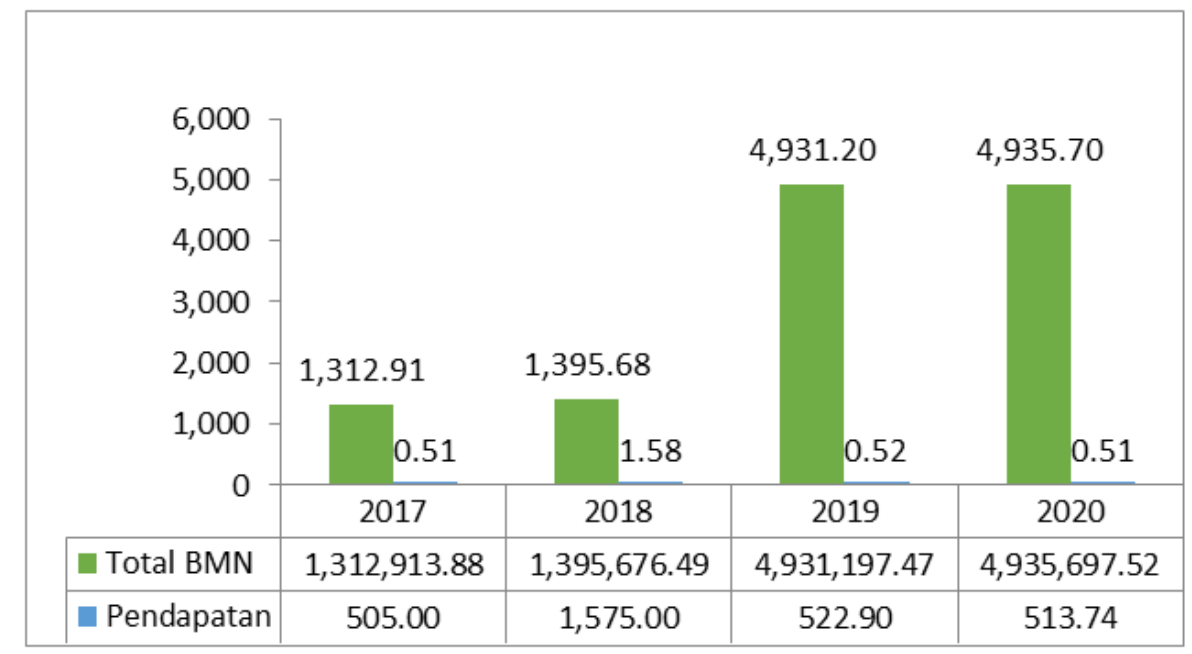

Fig. 2. Total BMN and Revenue in 2017 - 2020 (in Billion Rupiah)

Source: Data processed by the 2020 Central Government Financial Report (Audited)

This not yet optimal revenue from BMN utilization can of course be caused by several factors, one of which is the lack of proposals for BMN utilization submitted by Property Users. Jeremy Bentham's view of legal utilitarianism theory is that in the formation of legislation such as the Appraisal Act, it must be able to provide optimal utility for the entire community, so that no one is harmed the legislation must strive to achieve four goals:

1. to provide subsistence (to provide a living);

2. to provide abundance (to provide abundant food);

3. to provide security (to provide protection);

4. to at- tain equity (to achieve equality).[20]

Jeremy Bentham's view of legal utilitarianism theory is that in the formation of legislation such as the Appraisal Act, it must be able to provide optimal utility for all society, so that no one is harmed. Furthermore, the concept of Legal Economic Analysis by Posner using the approach and use of analysis is prepared with economic considerations without eliminating the element of justice, so that justice can become an economic standard based on three basic elements, namely value, utility. ), and efficiency (efficiency) which is based on human rationality.[21]

BMN Assessment Activities are central to BMN Management. BMN assessment requires the optimal value of a proposed BMN utilization. One of the activities that can be carried out 
by the DJKN Internal Assessor is to analyze the highest and best use. Guidelines for analyzing the highest and best use have been stated in the Decree of the Directorate General of State Assets No. 184/KN/2013 concerning Guidelines for Analysis of the Highest and Best Use of Land or Land and Buildings.

The highest and best use analysis originated from a concept from economist Irving Fisher (1867-1947) who put forward the idea of maximum productivity of a property.[22] The highest and best use is the use that will result in the highest value for the property, regardless of the actual use. The analysis of the highest and best use includes 4 (four) main points, namely:

\section{a) Regulatory Feasibility Analysis (Legally Permissible)}

This analysis relates to regulatory provisions, for example in the form of zoning (land allocation), KDB (Basic Building Coefficient), KLB (Building Area Coefficient), maximum height of buildings, road boundaries and other provisions on General Spatial Planning $(\mathrm{RUTR} / \mathrm{W})$. which is very influential on alternative properties that can be developed. This analysis examines whether a property or alternative property to be developed on a particular plot of land is supported or permitted by the existing regulatory provisions. With a good understanding of the importance of land legality, it is hoped that Property Users will be even more motivated to carry out the BMN certification process. Regarding zoning (land designation), if the surrounding zoning is commercial, the Property User can propose the use of BMN in the form of Utilization Cooperation (KSP) for a commercial property, but by still asking for a building room to be made for a place of work or other infrastructure related to its duties and functions.

\section{b) Physical Feasibility Analysis (Physically Possible)}

This analysis deals with matters relating to the physical characteristics of the soil in the form of location, area, shape, contour, or soil properties that affect alternative properties that can be developed on it. Regarding size, for example, a plot of land with a size of $500 \mathrm{~m} 2$ is not suitable for a five-star hotel to be built, but it is more suitable if it is built as a residence. A plot of land with uneven land contours but has a beautiful view like in the Puncak area, will be very suitable for property in the form of a hotel or villa. By understanding the physical condition of the land, Property Users are expected to have the initiative to propose the ideal type of utilization. Property users can actively search for potential utilization partners based on the location of their land. For example, for land located in urban areas, with an adequate area, it would be appropriate to propose a form of utilization in the form of a shopping center, hotel, or education center. On the other hand, for land located on the outskirts of the city, it can be proposed to use it in the form of a factory, or a warehousing facility.

\section{c) Financial Feasibility Analysis (Financially Feasible)}

This analysis relates the positive net income that a property can generate. A property is said to be financially viable when it can provide a positive net income. Commonly used financial measurement tools are Payback Period (PP), Internal Rate Of Return (IRR), and Net Present Value (NPV). To estimate the income from an alternative property, a market analysis is needed by comparing it with similar properties. Analysis of potential revenues and costs is important. How much positive net income is expected to be adjusted according to the investment preferences to be made. By knowing the potential revenue and costs of alternative uses of BMN 
that can be done, Property Users can better ensure that the utilization of BMN that will be carried out is financially feasible. Utilization of BMN does not mean knowing how to keep the asset from being idle, but it must be ensured that its utilization is profitable.

\section{d) Maximum Productive Analysis (Maximally Productive)}

This analysis relates to the best financial benchmark among several proposed property development alternatives. If after analysis it is found that two or more alternative properties are legally permitted, physically and financially feasible, then the next selection is based on which alternative property has the best financial benchmark. By understanding this analysis, it is hoped that the Property User will be able to know that for a land asset, it is possible to have several alternative uses of BMN, all of which are profitable, but there will be one that provides the maximum benefit.

Efforts to provide an understanding regarding the analysis of the highest and best use can be done by holding outreach activities. Socialization activities related to the urgency of understanding the analysis of the highest and best use can be carried out to Property Users at the Work Unit level initiated by the Assessment Sector in collaboration with the State Asset Management Sector. From this socialization activity, it is expected that Property Users at the work unit level can carry out self-introspection to re-invent assets that have not been used optimally according to the criteria for the highest and best use, to then carry out an analysis of the highest and best use independently or in collaboration with the Assessment Division, to further propose utilization to the Property Manager.

The purpose of utilizing BMN assets is widely used for toll road construction projects, telecommunication networks, especially in buildings. This is a prospective business area for investors to invest in these objects. Investing in the right object can provide benefits for investors. Investors have the principle that, a land always has one best use and one purpose of property use which always requires a certain site. One of the analyzes that can provide input for making the best investment is the Highest and Best Use (HBU) analysis. So, HBU analysis needs to be done before investing in commercial properties that provide the highest income value

3.2 The Arrangement of The System for Determining The Rights and Obligations of Users of State/Regional Property Taken into Account The Utilization with The Concept of Economic Value on The Implementation of The Utilization of State Property in The Form of A Cooperation Scheme of Lease Agreement or Build-to-Delivery (BOT)

Optimizing BMN assets to support the APBN has become a hot issue in the midst of the government's efforts to increase state revenues. Such great attention to infrastructure development requires no small amount of financing. For this reason, potential sources of state revenue must continue to be explored. Utilization of assets that can generate income becomes an attractive alternative, given the large value of the assets we have. Utilization of BMN is widely used for toll road construction projects, telecommunication networks, especially in buildings. This is a prospective business area that can contribute significantly to state revenues.

But in fact, the contribution of the use of BMN to state revenues is still far from expectations. According to LKPP data for 2020, the total realization of revenue related to the management of $\mathrm{BMN}$ is only IDR 0.51 trillion. This amount of revenue is considered too small, considering the large value of BMN which reached Rp4,935.69 trillion. When compared to the total value of 
BMN, the return on assets (RoA) of BMN is very low, only reaching $0.10 \%$. The value of assets listed in the LKPP balance sheet shows the resources owned by the central government in an effort to achieve its goals. One of them, as stated in the preamble to the 1945 Constitution, is to promote public welfare. Looking at the proportions owned, BMN should be expected to play a significant role in efforts to achieve these goals. For this reason, optimal and accountable management must continue to be carried out.

Table 1. Income from Utilization of BMN in LKPP 2020

\begin{tabular}{|r|l|r|r|}
\hline \multirow{2}{*}{ MAP } & \multicolumn{1}{|c|}{ Jenis Pendapatan } & \multicolumn{1}{|c|}{$\begin{array}{r}\text { Realisasi } \\
\text { (Rp) }\end{array}$} & $\begin{array}{r}\text { Komposisi } \\
(\%)\end{array}$ \\
\cline { 2 - 4 } & \multicolumn{1}{|c|}{} & & \\
\hline 42513 & Pendapatan dari Pemanfaatan BMN & 441.318 .174 .033 & $85,90 \%$ \\
\hline 425131 & Pendapatan dari Sewa Tanah, Gedung, dan Bangunan & 996.070 .765 & $0,19 \%$ \\
\hline 425132 & Pendapatan dari Sewa Peralatan dan Mesin & 2.395 .464 .844 & $0,47 \%$ \\
\hline 425133 & Pendapatan dari Jalan, Irigasi, dan Jaringan & 39.884 .325 .808 & $7,76 \%$ \\
\hline 425134 & Pendapatan dari KSP Tanah, Gedung, dan Bangunan & 0 & $0,00 \%$ \\
\hline 425136 & Pendaptan dari KSP Jalan, Irigasi, dan Jaringan & 2.366 .939 .546 & $0,46 \%$ \\
\hline 425137 & Pendapatan dari Bangun, Guna, dan Serah BGSI & 26.777 .228 .374 & $5,21 \%$ \\
\hline 425139 & Pendapatan dari Pemanfaatan BMN Lainnya & $\mathbf{5 1 3 . 7 3 8 . 2 0 3 . 3 7 0}$ & $\mathbf{1 0 0 , 0 0 \%}$ \\
\hline \multicolumn{2}{|c|}{ Jumlah } & & Source: Central Government Financial Report 2020 (Audited)
\end{tabular}

Utilization of State-Owned Goods, the forms of utilization of BMN that can generate revenue are expanded into leases, KSP, build-to-delivery (BGS)/build-up handovers (BSG), and cooperation in infrastructure provision (KSPI). Apart from the forms of utilization that have been regulated in the regulation, there are actually other forms of asset utilization that can be carried out. The forms of utilization are concessions and joint operations (management and operating agreements). The characteristics of these forms of utilization are summarized in the following table:

\section{a) Rent}

Lease is the use of BMN by other parties for a certain period of time and receiving cash rewards. BMN leasing is carried out with the aim of optimizing the utilization of BMN that has not been/not used in the implementation of the duties and functions of state government administration. The maximum period of BMN Lease is 5 (five) years. The formula for rental rates/amounts is determined by the Property Manager, for BMN in the form of land and/or buildings; or Property Users with the approval of the Property Manager, for BMN in the form of other than land and/or buildings. Rent payments are made at once in advance by depositing it into the State General Treasury account.

\section{b) Utilization Cooperation (KSP)}

Utilization Cooperation is the utilization of BMN by other parties within a certain period of time in the context of increasing non-tax state revenues and other financing sources. KSP is implemented in order to optimize the usability and efficiency of BMN and increase state revenue. The results of the KSP are in the form of land, buildings, buildings, facilities and facilities built in the context of implementing the KSP to become BMN after the end of the implementation of the cooperation. The maximum period of KSP is 30 (thirty) years and can be 
extended. Contributions to state revenues are in the form of fixed contributions and profit sharing. Contributions are still calculated based on a certain percentage of the value of BMN which is the object of KSP. Meanwhile, profit sharing is calculated by taking into account the amount of BMN which is considered as government investment, the investment value of KSP partners and the risk borne by KSP partners. The amount of the fixed contribution and profit sharing is determined by the Property Manager, for BMN who is in the Property Manager and Property User with the approval of the Property Manager, for BMN who is in the Property User.

\section{c) Build Operate Transfer (BGS) / Build Trasfer Operate (BSG)}

Bangun Guna Serah (BGS) is the utilization of BMN in the form of land by another party by constructing buildings and/or facilities along with their facilities, then utilized by the other party within a certain agreed period of time, to subsequently hand over the land along with the buildings and/or facilities and their facilities after expiration of the term. While Build Handover is the use of BMN in the form of land by another party by constructing buildings and/or facilities and their facilities, and after the construction is completed, they are handed over to be utilized by the other party within a certain agreed period of time. BGS/BSG is carried out with the consideration that Property Users need buildings and facilities for the administration of state government for the benefit of public services in the context of carrying out tasks and functions and there are not available or insufficient funds available in the State Revenue and Expenditure Budget for the provision of such buildings and facilities. Contributions to state revenues are in the form of annual contributions that must be deposited into the State General Treasury account every year. The amount of the annual contribution is determined based on the calculation results of the team formed by the authorized official. In addition to contributions in the form of receipts, some BGS/BSG objects can be used for tasks and functions according to the determination of the Property Manager/Property User.

\section{d) Cooperation in the Provision of Infrastructure (KSPI)}

Infrastructure Provision Cooperation is cooperation between the government and business entities for infrastructure provision activities in accordance with the provisions of laws and regulations. KSPI is carried out with considerations in the context of public interest and/or infrastructure provision to support government duties and functions, not available or insufficient funds available in the State Revenue and Expenditure Budget for infrastructure provision, and are included in the list of priority projects for infrastructure provision programs set by the government. The maximum period of KSPI is 50 (fifty) years. After the implementation of KSPI, KSPI objects and KSPI products are handed over to the government and become BMN since they were handed over. In addition to acquiring assets, the implementation of KSPI can also contribute to state revenues in the form of sharing excess profits. The amount of the excess profit is determined by the goods manager.

\subsection{Application of the Principle of Proportionality in Commercial Property Development Through the Build Operate and Transfer (BOT) Model}

Commercial property development in the form of toll road construction projects, telecommunication networks, especially in buildings is a prospective business area to increase the optimization of BMN assets. The limited government funds in building the development of central and regional commercial property are bridged through the government's policy of 
agreement with the private sector as investors, one of which is the Build Operate and Transfer (BOT) model.[23] BOT in the context of infrastructure project procurement is a contract or agreement between the project owner (government) and other parties as investors to build a (general) facility and infrastructure at the full expense of a private company, several private companies, or in cooperation with BUMN and operate it for a long period of time. certain time and take all or part of the profits and at the end of the contract period must return the project to the project owner.[24]

Clifford W. Garstang, stated that BOT is: "is a variety of type of project financing known as contractor provided financing. In the standard contractor provided financing a project entity may request proposal for the construction of a project pursuant to which the contractor will not only provided the materials and services needed to complete the project but will also provide or at least arrange the necessary financing. The contractor will also need to operate the project and use its cash flows to repay the debt it has incurred".[25]

The implementation of commercial property development through the BOT model provides benefits for both parties, both for the government as the owner of state property as well as for investors as those who have funds. The private sector (investor) can carry out development to carry out business activities without having to own goods (assets) or land. For the government that owns state property and when optimizing it/utilizing it requires very high costs which will interfere with the use of APBN/APBD funds, then in the short term, with BOT the government will benefit from not only getting financing for project development, but also getting compensation. or royalties from the management of the project. In the long term, the benefits received by the government are that after the BOT period ends the government will get infrastructure projects along with supporting facilities and infrastructure, so that this BOT agreement will not only not interfere with the use of APBN/APBD funds, but can also have an impact on increasing revenue. government finances, both during construction, operation, and at the time of delivery of infrastructure projects.

The smooth implementation of the BOT agreement will facilitate and expedite the tasks and services of the government to the community as an effort to realize the national development goals for the welfare of the community. Profits for investors, infrastructure development through BOT provides an opportunity to take part in the handling and operation of projects that have the potential to bring profits which are usually monopolized by the government itself, expand business to other fields that have good and profitable prospects, and create new fields and business climates.

However, the BOT concept in infrastructure development cannot be separated from the risks both faced by the government and by investors. In some cases the government is asked to implement and resolve complex and vulnerable problems, for example in the construction of toll roads related to land or land acquisition, as well as the possibility of default on the part of investors. For investors, the business carried out contains many risks, such as political risk, legal risk, economic and market risk, as well as the risk of forced circumstances (overmacht), so that it requires careful calculation, consideration, and preparation to implement infrastructure development financing through this BOT model.

Considering the magnitude of the risks that arise as well as the complexity of the use of state property in infrastructure development through the BOT concept, because its implementation consists of several stages starting from the development stage, operation/implementation stage, and delivery stage, as well as the spread of various rules regarding the construction of commercial property development projects through this model. BOT, then its implementation must be based on the principles of the agreement, one of which is the principle of proportionality so that a mutually beneficial contractual relationship is established. 
The principle of proportionality is the principle that underlies or underlies the exchange of rights and obligations of the parties according to the proportion or part thereof in the entire contractual process, both in the pre-contractual phase, contract formation, contract execution, and contract termination.[26] The application of the proportional principle in the utilization of state assets through the Build Operate and Transfer (BOT) model can be carried out through the following stages:[27]

\subsubsection{Pre-Contract Phase}

In this phase, the principle of proportionality is realized from the fulfillment of the conditions for the validity of the contract as stipulated in Article 1320 of the Civil Code, namely:

\section{a) The Parties Agree to Bind Themselves (De Toestemmig Van Degenen Die Zich Verbinden)}

An agreement is a statement of the will of the parties that has an important role as the initial basis for the formation of a contract, which is formed by two fundamental elements, namely offer and acceptance.[28] An offer (offer, aanbood) is a statement of will that contains elements to enter into an agreement, while acceptance (acceptance, aanvaarding) is a statement of approval from another party who is offered.[29] In the event that there is a discrepancy between the statements of will of the parties caused by a defect of will, due to an unfair exchange of rights and obligations, the contract may be filed for cancellation (vernietigbaar) by the injured party. Defects of will (wilsgebreke) that hinder the realization of the principle of proportionality, can be caused by the following factors:

1. Misguidance (dwaling), namely an error regarding the facts or laws that existed when the contract was concluded.

2. Coercion (dwang), where someone gives an agreement because of a threat that is against the law, thus moving the other party to give an agreement because he is forced to.

3. Fraud (bedrog), which is carried out by another party as a series of deception (kunstgrepen) that causes someone to move to make an agreement.

4. Misuse of circumstances (misbruik van omstandigheden), which is a condition where one of the parties still closes the contract even though he actually knows or should know that the person concerned should not close the contract.

\section{b) Ability to Make Engagements (De Bekwaamheid Om Eene Verbintenis Aan Te Gaan)}

The ability to carry out legal actions independently without being contested whose measurement standards for person (personal) are maturity (meenderjarig), and rechtspersoon (legal entity) from the aspect of authority (bevoegheid) attached to the party who represents it.

\section{c) A Certain Thing (Een Bepaald Onderwerp)}

It is the performance that is the subject of the agreement that determines the nature and extent of the statements to which the parties are obliged.

\section{d) A Lawful or Permissible Cause (Eene Geoorloofde Oorzaak)}


Subekti argues that what is meant by cause (cause) is the content of the agreement which is the achievements and counter-achievements that are exchanged by the parties, while H.F.A. Vollmar and Wirjono Prodjodikoro, provide the understanding of cause (causa) as the intent or purpose of the parties to conclude the contract. For example, in a BOT contract for the construction of a commercial property development project, the purpose of the parties closing the contract is to grant rights from the government to investors to build projects on state property, operate them, and when the BOT period is over, all projects developed are handed over to the government.

A contract has no binding legal force if the contract does not have a cause, the cause is contrary to the law, contrary to morality, and contrary to public order, which results in the existence of the contract being null and void.

\subsubsection{Contract Implementation Phase}

In this phase, the principle of proportionality is realized by the implementation of clauses in the contents of the contract that have been agreed upon by the parties based on the principle of freedom of contract or those based on the clauses according to Presidential Regulation no. 67 of 2005 concerning Government Cooperation with Business Entities in commercial property development projects, as amended three times by Presidential Decree no. 13 of 2010, Presidential Regulation No. 56 of 2011, and finally Presidential Decree 66 of 2013, which contains clauses on: (a) Scope of work; (b) Term; (c) Performance guarantee; (d) Tariffs and adjustment mechanisms; (e) Rights and obligations including risk allocation; (f) Service performance standards; $(\mathrm{g})$ Prohibition of the transfer of cooperation agreement or share participation in the business entity holding the cooperation agreement before the commercial property operates commercially; (h) Sanctions in the event that the parties do not comply with the provisions; (i) Termination of the agreement; (j) Financial statements of business entities in the context of implementing the agreement, which are audited annually by independent auditors, and their announcements in print media on a national scale; $(\mathrm{k})$ Dispute resolution mechanisms; (1) Mechanism of monitoring the performance of business entities in the implementation of the agreement; (m) Return of commercial property and/or its management to the minister/to institutions/regional heads; (n) Forced circumstances; and (o) Indonesian law as applicable law.[26]

The contract as an instrument of exchange of rights and obligations of the parties, both at the pre-contract stage, contract formation, implementation, and delivery of the object of the contract is expected to be carried out properly, fairly and proportionally.

However, talking about business cannot be separated from the risk of possible contract failure (default or non-fulfillment or also known as breach of contract) both caused by internal and external factors. According to Mariam Darus Badrulzaman, there are three forms of default, namely: First, the debtor does not fulfill the engagement at all; Second, the debtor is late in fulfilling the engagement; and third, the debtor is wrong or does not deserve to fulfill the engagement.[27]

In accordance with the provisions of Article 1267 of the Civil Code, the rights of creditors against debtors who are in default in carrying out the contract, in the form of: (1) Fulfillment (nakoming) achievements; or (2) Compensation (vervangende vergoeding; schadeloosstelling); or (3) Dissolution, termination or cancellation (ontbinding); or (4) Fulfillment plus complementary compensation (nakoming en anvullend vergoeding); or (5) Dissolution plus complementary compensation (ontbinding en anvullend vergoeding).[30] 
One of the most important consequences of non-fulfillment of the engagement is giving the creditor the right to be able to ask for compensation as a sanction for the debtor to provide reimbursement of costs (kosten), losses (schaden), and interest (interest). However, according to Article 1238 of the Civil Code, the claim for compensation can only be made after a statement of negligence "in mora stelling/ingebereke stelling" is given from the creditor to the debtor in written form (bevel of sorgelijke akte) with the aim of giving a grace period to the debtor. to fulfill their performance. In addition, according to Munir Fuady, the creditor's claim for compensation is also subject to limitations, which in contract law are known as several legal doctrines on the limitation of compensation from default, namely:[31]

1. The doctrine of predictability, that compensation can only be given to the extent that the loss is foreseeable (foreseeable) at the time the contract is signed, unless there is an arglist.[31] Furthermore, Asser'r-Losecaat Vermeer states that arglists are debtors who intentionally and consciously violate their obligations regardless of whether or not the debtor's intention is to cause losses.[32]

2. The doctrine of rational certainty (reasonable certainty), that compensation can only be given up to an amount that can be estimated with certainty and reasonable (reasonable certainty). Compensation that does not meet the element of "definite and reasonable estimation" is said to be compensation that is "speculation" and therefore according to this doctrine the compensation cannot be justified.[31]

3. Mitigation Doctrine/Avoidable Consequences Doctrine, which teaches that even though the debtor has defaulted, the creditor as the aggrieved party has an obligation to reduce the loss (duty to mitigate damages). The loss suffered by the creditor, because the creditor himself does not try rationally (reasonable effort) to prevent the spread of the loss, cannot be asked for compensation from the debtor.[31]

4. The doctrine of causality, in line with the provisions of Article 1248 of the Civil Code, that a compensation can only be justified if the loss is actually caused by a default of the contract in question,[31] the solution of which can be done through two theories, namely:

\section{a) Condition Sine Qua Non (Von Buri)}

According to this theory an effect is caused by various events that cannot be excluded for the existence of an effect. These various events are a unity called "cause". The teaching of conditio sine qua non, holds that all conditions that cannot be eliminated for the existence of an effect are equal and assume that every condition is a cause. This teaching has received opposition from various parties and is impossible to apply in legal practice, because this theory expands accountability.

\section{b) Adequate Veroorzaking (Von Kries)}

This theory argues that a condition is a cause, if by its nature it is generally capable of causing an effect. Furthermore, Hoge Raad provides the formulation, that an action is a cause if according to experience it can be expected/predicted that the result in question will occur. Hoge Raad adheres to the adequate teaching, which is formulated that what is meant by immediate and immediate consequences are consequences that according to experience can be expected to occur.[32]

Based on the principle of proportionality, the law also gives the same award to debtors to maintain their contractual rights, where debtors can release their responsibility to provide compensation if they can prove that the non-fulfillment of the contract is not due to negligence 
but due to overmacht, which is generally regulated. contained in the General Part of Book III of the Civil Code Article 1244, Article 1245, and Article 1444.

Overmacht is a situation that occurs after the engagement is made that prevents the debtor from fulfilling his achievements, where with the overmacht the debtor cannot be blamed, does not have to bear the risk and the debtor cannot suspect that this situation existed at the time the agreement was made, and all of this happened before the debtor negligent to fulfill its performance.[31]

In addition to overmacht, debtors can also use the legal doctrine of "waiver of rights" (rechtsverwerking) which is based on the creditor's attitude either explicitly (firmly) or implicitly (tacitly) accepting the debtor's achievements even though it is not in accordance with what was agreed upon, as well as the doctrine of "exeptio non edimplete contractus", which is a defense for the debtor against the creditor's claim that the achievement is not carried out, because the creditor himself does not carry out the achievement.

In line with the principle of proportionality, the risks due to non-utilization of state assets in the development of commercial property through BOT due to overmacht, as well as risks due to political factors, legal risks, economic risks, as well as market and income risks are the responsibility of creditors and debtors. These risks need to be carefully calculated by the parties, the settlement of which is usually carried out through the use of insurance or coverage institutions as parties who will provide guarantees if these risks actually occur in the BOT agreement.[33]

\subsubsection{Post-contract/Submission of BOT Objects}

In this phase, the principle of proportionality is realized by the implementation of contractual rights and obligations by the parties based on good faith, so that the goal of closing the contract to obtain mutual benefits can be achieved. With the expiration of the contract, the investor will benefit from the operation of the infrastructure object, and the government as the asset owner will receive the delivery of the BOT commercial property object and its supporting facilities and infrastructure, without the government issuing any funding.

The high level of commercial property development in Indonesia often creates different interpretations that lead to disputes between the government as an employer and investors. This is due to the nature of commercial property development work through a dynamic BOT model. The term "Disputes" or Disputes (English), is often referred to as "Conflict" or Conflict (English),[34] namely a perceived divergence of interest between two or more parties to a situation or object followed by a claim. on the one hand and rejection on the other.[35]

Henry Campbell Black explained the meaning of "Dispute", as: "A conflict of controversy; a conflict of claims or rights; an assentation of a right, claim, or demand on one side, met by contrary claims or allegations on the other. The subject of litigation; the matter for which a suit is brought and upon which issue is joined, and in relation to which jurors are called and witnesses examined." [36]

There are several factors that cause conflicts in the development of commercial property through this BOT, among them due to: (a) Inappropriate and imperfect contracts (inappropriate contract type); (b) Lack of competence of project participants; (c) Lack of professionalism of project participants; (d) the client does not obtain correct information so that he/she is doubtful (client's lack of information or decisiveness); (e) Providing unrealistic information expectations by contractors; (f) Unbalanced and unclear risk allocation; (g) Unrealistic target of cost, time and quality (unclear risk time/cost/quality by client); (h) Uncontrollable external events; (i) 
Competition due to culture (adversariaindustry culture); (j) Unrealistic tender pricing and (k) Improper and imperfect contracts (inappropriate contract type).[37]

In general, disputes/conflicts in the development of commercial property can be caused by two factors, namely human quality factors and factors beyond human control, such as unstable political, economic and security factors, environment (culture), changes in legal regulations and geographical conditions. The impact of the dispute is that the business relationship between the parties is disrupted, the productivity of the implementation of the construction project object is lost, as well as the length of time and the high cost required to resolve the conflict.[38]

To avoid this, in a commercial (commercial) business contract, the parties include a dispute settlement clause or midnight clause through two options, namely: (1) Settlement through litigation; and (2) non-litigation settlement. The pattern of dispute resolution using the ADR mechanism or through the courts, both of which are manifestations of the application of the principle of proportionality as stipulated in Article 1865 of the Civil Code and Article 163 of the HIR, that there is a balanced distribution of evidence, where whoever postulates something, gives him an obligation to prove the rights he argues for. Likewise, whoever submits a rebuttal argument, to circumvent the rights argued by another party, is given the burden of proof to prove the rebuttal argument. In the Common Law legal system, according to Raymond Emson, this principle is called the standard "burden of proof" which applies as a general rule in the distribution of the burden of proof, known as the sentence "He who asserts must prove", that whoever states something must prove it.[30]

In relation to the settlement of this dispute, Basuki Reso Wibowo expressed his view that there has been a shift in the proceedings in the court which is no longer based on the enforcement of substantial justice, but becomes a force to beat each other (to be the winner, not the loser),[39] so that it does not guarantee legal certainty is not responsive to the public interest, does not solve problems because it is oriented to legal facts (finding the guilty party, slow settlement of cases), resulting in high costs of solving problems and taking quite a long time.[40]

\section{Conclusion}

Based on the description that has been stated above, the following conclusions can be drawn:

1. The analysis of the highest and best use is an analytical tool that is important to be understood and applied by the Ministry/Leading Institution as a User of Goods in the context of BMN Management. The role of the Directorate of Assessment to increase the capacity of DJKN's Internal Appraisers to be more capable in conducting analysis of the highest and best use is very necessary.

2. The low contribution of asset management to revenue does not necessarily mean that BMN management has not been carried out optimally. To assess its optimization, it is necessary to map the potential utilization of assets for the utilization of BMN. This is the right policy and strategy that is made based on the results of the analysis of adequate information and data (evidence-based decision making process).

3. The State of Indonesia as a welfare state guarantees the availability of adequate public goods that can be enjoyed by all levels of society, both in the form of public services and government functions, through optimization of state-owned assets. However, the government has limited funding, both through the APBN and APBD, in providing infrastructure development as a means to improve the welfare of the community. In response to these problems, the government has developed mutually supportive and beneficial 
partnership relationships between large and small companies, both national and foreign companies, one of which is through the Build Operate and Transfer (BOT) model.

4. The implementation of infrastructure development through the BOT model provides benefits, both for the government as the owner of state goods as well as for investors as those who have funds. However, infrastructure development through the BOT model cannot be separated from risks considering the complexity of the BOT agreement which is carried out through the development, operation, and delivery stages. Therefore, its implementation must be based on the principle of proportionality so that a mutually beneficial contractual relationship is established for the parties, both when:

a. The pre-contract phase, which is manifested by the fulfillment of the conditions for the validity of the contract as regulated in Article 1320 of the Civil Code, namely (1) Agreeing on the parties to bind themselves; (2) the ability to make engagements; (3) A certain thing (een bepaald onderwerp); and (4) A lawful or permissible cause (eene geoorloofde oorzaak).

b. The Contract Implementation Phase, which is realized by the implementation of the contractual content clauses that have been agreed by the parties in good faith.

c. The post-contract phase is manifested by the implementation of contractual rights and obligations by the parties, where the investor benefits from the operation of the infrastructure object, and the government as the owner of the asset gets the delivery of the BOT infrastructure object along with its supporting facilities and infrastructure, without the government issuing any funding.

\section{References}

[1] Philip Schofield, Utility And Democracy The Political Thought of Jeremy Bentham, (Printed in Great Britain on acid-free paper by Biddles Ltd., King's Lynn, Norfolk), 2006

[2] Evelyne Serverin, Law And Economics In Civil Law Countries (Masscahusetts: Addison-Wesley, 2001),

[3] M.D.A. Freeman, Interoduction to Jurisprudence (London: Sweet \& Maxwell Ltd., 2001

[4] A.V. Dicey, Introduction to the Study of the Law and the Constitution (London: McMillan and Co.) 1952

[5] David Held, Models of Democracy (Oxford: Blackwell Publisher Ltd., 1997)

[6] Media Indonesia, Media News Directorate General of State Finance (DJKN), Total State Assets Increase, BPK Appreciates Ministry of Finance, Tuesday, 23 October 2018, p. 13.

[7] Frans Limahelu, 2020. The Existence of Functions, and the Purpose of Law,

[8] Indonesian Assessment Code of Ethics and Indonesian Assessment Standards VIII-2018 Edition, (Pedoman Penilaian Indonesia 10), 2018

[9] Public-Private Partnership. (Media Kekayaan Negara), Edisi No.17 Tahun V/2014

[10] E. R. Yescombe, Public-Private Partnerships Principles of Policy, (Printed and bound in Great Britain) 2007

[11] Government Regulation of the Republic of Indonesia Number 28 of 2020 concerning amendments to Government Regulation (PP) Number 27 of 2014 concerning Management of State/Regional Property.

[12] Zuldan Arif Fakruloh, 2011. Institutional Science and Legal Institutions, Kharisma usaha offset, Jakartapoliti 
[13] Media Kekayaan Negara, Refleksi Dan Apresiasi Pengelolaan Barang Milik Negara Pada Kementerian/Lembaga,Edisi No.11 Tahun III/2014

[14] Victoria, Agatha Olivia. BPK Temukan Tiga Masalah Pengelolaan Aset Gelora Bung Karno. (2021). Derived from https://katadata.co.id/agustiyanti/finansial/60a3ec58d4404/bpk-temukan-tiga-masalahpengelolaan-aset-gelora-bung-karno

[15] Perjanjian Aset oleh Jakarta International School (JIS) . Jakarta, Modus operandi, 5 April 2013., Op.Cit. Pasal 20 ayat (1)

[16] Sulistiowati, Tri. Kasus Kempinski, HIN Dinilai tak Paham BOT. Editor: Adi Wikanto. Derived from https://nasional.kontan.co.id/news/kasus-kempinski-hin-dinilai-takpaham-BOT

[17] Assidiqi, Jimly. Penegakan Hukum.

[18] Edi Suharto, Building a Community Empowering People: A Strategic Study of Social Welfare Development and Social Work, (Bandung: Refika Aditama, 2005), p. 50, and Darmawan Triwibowo and Sugeng Bahagijo, The Dream of a Welfare State, p. XV

[19] Oman Sukmana, Concept and Design of the Welfare State, "Jurnal of Sospol", Vol. 2, No.1, 2016, 103-122, p. 103

[20] Ali, Achmad. Revealing Legal Theory \& Judicial Prudence: Including the Interpretation of Laws (Legisprudence) Volume I Initial Understanding, Jakarta: Kencana, 2009, p. 76

[21] Sugianto, Fajar. Economic Analysis of Law: Series I Introduction to Economic Analysis of Law. Kencana, Jakarta, p. 45 (2013)

[22] J.F.N. Murray in John L. Cooper. Course-packet Module 2 on Indonesia-Australia Training Specialist Phase II AusAID, Work-hop on Asset Appraisal for Financial Restructuring. Jakarta, 2002. p. 2 which in its original version states: "The theory of valuation is a pragmatic extension of economic theories relating to value and price, but it is remarkable to find that there is an almost complete dissociation between economic theory and the theory of valuation" ( $p$ 82)

[23] Vita Justitia, Build Operate Transfer Agreement between the Provincial Government of South Sumatra and the Private Sector, "Jurnal Conscience", Vol. 15, No. 1, 2015, 73-84, p. 74, and I Gede Abdhi Prabawa, Legal Studies on Build Operate Transfer (BOT) Agreements to Protect Land Ownership Rights to Support the Tourism Sector, "Student Legal Journal", 2013, p. 2.

[24] Then Hadi Adha, Lalu Hadi, Build Operate Transfer Contracts as Government Policy Agreements with Private Parties, "Journal of Legal Dynamics", Vol. 11, No. 3, 2011, 548-558, p. 549, and Ikka Puspitasari and Budi Santoso, Public-Private Cooperation Agreement with the Build Operate Transfer (BOT) Pattern in Toll Road Development (Study of Semarang-Solo Toll Road Development), "Jurnal Law Reform”, Vol. 14, No. $1,2018,57-73$, p. 58.

[25] Clifford W. Garstang, Sidley \& Austin Singapore, BOT Arrangement, BOT \& Project Finance, (Jakarta: Conference, 7 October 1992).

[26] Agus Yudha Hernoko, Agreement Law on the Principle of Proportionality in Commercial Contracts, (Jakarta: Prenada Media Group, 2014), p. 87.

[27] Mariam Darus Badrulzaman, Various Business Laws. Alumni, Bandung (1994)

[28] E. Allan Fransworth and William, F. Young, Countracts (Cases \& Materials), (New York: The Foundation Press Inc., 1980), p. 179

[29] H.F.A. Vollmar, Introduction to the Study of Civil Law, Volume II, translated by I.S. Adiwimarta, (Jakarta: RajaGrafindo Persada, 1995) 
[30] Hernoko, Agus Yudha. Covenant Law on the Principle of Proportionality. Prenanda Media Group (2014)

[31] Fuady, Munir. Contract Law (From a Business Law Perspective). Book I. Citra Adiyta Bakti, Bandung, p. 137-169 (2011)

[32] R. Setiawan. Principles of Engagement Law. Binacipta, Bandung (1987), p. 24.

[33] Fuady, Munir. Modern Corporate Financing, Business Law Review, (Bandung: PT Citra Aditya Bakti, 1997)

[34] Echols, John M., and Hassan Shadily. English Indonesian and Indonesian English Dictionary. Gramedia, Jakarta (1996)

[35] Jawahir Tantowi and Pranoto Iskandar, Contemporary International Law, (Bandung: Refika Aditama, 2006), p. 224, and Sudjana, Effectiveness and Efficiency of Intellectual Property Dispute Resolution Through Arbitration and Mediation Based on Law Number 30 of 1999, "AJUDIKASI Jurnal Ilmu Hukum", Vol. 2 No. 1, 2018, 81-96, p. 85.

[36] Henry Campbell Black, Black’s Law Dictionary, (St. Paul: West Publishing Co., 1989), hal. 424.

[37] Abdurrasyid, Priatna. Arbitration \& Alternative Dispute Resolution: An Introduction. Fikahati Aneska in collaboration with BANI, Jakarta (2002)

[38] Karolus E. Lature. Analysis of Construction Dispute Resolution in Indonesia. Indonesian Legislation Journal. Vol. 15, No.3, pp. 214 (2018)

[39] Basuki Rekso Wibowo, Settlement of Business Disputes outside the Court (Speech) Delivered at the Inauguration of Professorship in Law, Universitas Airlangga, 17 December 2005, p. 8.

[40] M. Yahya Harahap, Civil Procedure Law, (Jakarta: Sinar Graphic, 2006), p. 14 and 160

[41] Aminuddin Ilmar. 2013. Governance Law. Identity of Hasanuddin University, Makassar.

[42] Astim Riyanto, 2009. Capita selekta Constitutional law, Yapemdo Publisher, Bandung, 2009

[43] Astim Riyanto, Constitutional Theory, fifth edition, Yapemdo, Bandung, 2017

[44] Bambang Waluyo, 2002, Legal research in practice, Sinar Grafika, Jakarta

[45] David M. Trubek and Alvaro Santos, The New Law and Economic Development, (Cambridge University Press) 2006

[46] Gatot Soemartono, Arbitration and Mediation in Indonesia, (Jakarta: PT Gramedia Pustaka Utama, 2006), p. 1

[47] Lexy J. Moleong, 2004, Qualitative Method, Remaja Rosdakarya, Bandung

[48] Marwan, Awaludin. Critical Legal Studies from Modern, Postmodern to Postmarxist. Semarang: Satjipto Rahardjo Institute and Thafa Media, 2012.

[49] Nurhan Bungi, 2003, Data Analysis and Qualitative Research, Philosophical and Methodological Understanding Towards Mastery of Application Capital, Raja Grafindo Persada, Jakarta

[50] Panggabean, HP. 2019, Application of Business Law Ethics in the Indonesian Judicial System, Jala Permata Aksara, Jakarta.

[51] T.J. Gunawan, 2018. The Concept of Punishment Based on the Value of Economic Loss, (Kencana, Jakarta).

[52] Surakhmad, Winarto. Basic and Research Techniques. Tarsito, Bandung. (1978)

[53] Article 5 paragraph (1) letter b PMK.No.57/PMK.06/2016 concerning Procedures for Leasing State Property

[54] Regulation of the Minister of Home Affairs Number 19 of 2016 concerning Guidelines for the Management of Regional Property; 
[55] Naskah Akademik RUU Pengelolaan Kekayaan Negara, Direktorat Jenderal Kekayaan negara,Kementerian Keuangan, disampaikan pada Focus Group Discussion Naskah Akademik RUU Pengelolaan Kekayaan Negara, Jakarta 15 Desember 2009

[56] https://kkp.go.id/itjen/artikel/30603-koordinasi-pemantauan-tindak-lanjut-hasilpemeriksaan-bpk-ri-pada-lk-2017-2019.

[57] https://nasional.kontan.co.id/news/bpk-ungkap-temuan-soal-pengelolaan-gelora-bungkarno-yang-belum-optimal 